\title{
Vaccination and Biopharming Technology
}

Rana Khalid Iqbal ${ }^{*}$, Javiera Khalid, Ayesha Tayyab, Mamoona Sattar, Farina Ansar, Sidra Aslam Nimra Kunwal and Muhammad Imran Qadir Institute of Molecular Biology and Biotechnology, Bahauddin Zakariya University, Multan, Pakistan

\begin{abstract}
Vaccination is very essential medical aid to prevent the onset of disease with the development of science and technology many advances occur in vaccination technology biopharming technology is most recent technology serving as a platform for vaccine development plant vaccine either in the form of capsules or injections presently and edibles for the future are most preferable for under developed countries and automated biopharming factories are working in this respect, the expression of proteins depends on the selected host system, intrinsic properties of desired protein. Nuclear transformation is most suitable and well-studied of all, biolistic transformation technology removes the need of vectors, but targeting is compromised. Stability of recombinant DNA can be maintained by over-expression of desired protein and optimization is achieved by the selection of suitable promoter, expression either stable or transient have utility. Finishing is done by downstream processing maximum protein extraction, costeffective processing with purification is yet a goal to be achieved.
\end{abstract}

Keywords: Vaccines; Plant factories; Biopharming; Recombinant proteins; Host system; Expression; Transformation

\section{Introduction}

Vaccination is the only way to get immunity before the onset of disease, vaccine consists of biological preparation that generates the immunity to a specific disease it may contain killed or weakened version of microbes or sometimes the disease is caused by the toxins produced by microbes, the vaccine contain toxin or a part of pathogen but not the whole microbe is called toxoid [1]. Subunit vaccines are getting popularity, specific proteins or the genes coding for disease-causing proteins are isolated from the disease-causing agent and introduced into another virus, conjugate vaccines are like subunit vaccines contain fragments from the coat of bacteria, which are chemically linked to a carrier protein. With the discovery of virus-like particles, the process of vaccine development further simplifies, single virus protein is isolated from different strains the expression of these proteins results in the creation of VLP [2]. They do not contain genetic material from viruses and so, cannot cause disease but incite the immune response. VLP for HBV, NV, and HPV have been produced in plants $[3,4]$. VLP is gaining interest because of their favorably compact structure which may allow them to withstand severe conditions gastrointestinal environment $[5,6]$. In the present review, our focus is on plant vaccines and their production through molecular pharming technology. Pakistan is a developing country, a report by UNDP Pakistan and OPHI, University of Oxford, 2016 shows that 4 out 10 Pakistani's life in multidimensional poverty, which makes $39 \%$ of total population common public cannot afford high cost of medical treatments and vaccination, according to another report by World health organization and UNICEF 2016 reveals that $70-80 \%$ of children are vaccinated and DTPcv3 coverage decreases from 2010 to 2016 from $82 \%$ to $72 \%$ in Pakistan by 2016 . Third world countries like Nigeria, Afghanistan, and South Africa are suffering from worst poverty keeping forward all these conditions edible vaccines will prove a boon to overcome the disease and death rates. In Pakistan GMO food is being consumed but the labeling law is absent, whereas, equity, consistency, and fairness is the basic human right $[7,8]$ maize, canola, cotton, and soybean are genetically engineered crops being used in different countries [9]. Other plants which are genetically engineered include poplar plant, gaining lots of interest [10]. Most recent development in biotechnology and bioengineering allows researchers to develop plant-based vaccines, plants are genetically manipulated [11] containing antigens to generate active immunity are called edible or green vaccines [12]. Plant-based vaccines are recombinant subunit vaccine, firstly the antigen to be expressed as capsid proteins are selected and these proteins are then expressed in plant tissues [13]. Production of pharmaceuticals in plants or animals is called biopharming, pharmaceuticals like antibodies, antigens, enzymes, hormones, anti-disease agents (e.g. Interferon and lactoferrin) and structural proteins (collagen) are produced in plants [14]. Now a day's vaccines, therapeutics, and proteins are being produced depending on the bacterial (E. coli) [15] mammalian and yeast cell expression system need high-cost purification, cold storage and are very expensive for patients to purchase [16] recent idea for oral delivery of plant-based vaccines therapeutic proteins and autoantigens this technology eliminates the need of cold storage, transportation, attenuated or inactivated pathogens, purification and sterile injections $[17,18]$. Genetically engineered crops are being adopted with the faster rate in developing countries [19] for this synthetic genetic circuits are used which may allow traits to be designed order in the future. Leaf and seed expression systems are used for proteins production latter is more suitable as it offers better storage for a long time other than these tows another way is suspension culture by using bioreactors for large-scale production, but the yield is compromised. cost of mammalian cell cultures, and all of this depends upon the product yield [20]. The principle advantage of transgenic plants for the atomic cultivating is generally minimal effort of vast scale generation, it is normal that recombinant proteins in plants might be delivered at $2-10 \%$ of the cost of microbial maturation frameworks and in addition $0.1 \%$ of the gene to protein duration for transgenic plants take up the preparation of expression construct, transformation, regeneration as well as the production and testing of numerous generations of plants, the testing part is essential to make sure transgene and its expression

*Corresponding author: Rana Khalid Iqbal, Institute of Molecular Biology and Biotechnology, Bahauddin Zakariya University, Multan, Pakistan, E-mail: Khalid.iqbal@bzu.edu.pk

Received September 24, 2018; Accepted October 23, 2018; Published October 30,2018

Citation: Iqbal RK, Khalid J, Tayyab A, Sattar M, Ansar F, et al. (2018) Vaccination and Biopharming Technology. J Biomol Res Ther 7: 168. doi:10.4172/21677956.1000168

Copyright: ( 2018 Iqubal RK, et al. This is an open-access article distributed under the terms of the Creative Commons Attribution License, which permits unrestricted use, distribution, and reproduction in any medium, provided the original author and source are credited. 
stability as well as biochemical activity of the product and the absence of undesirable phenotypic changes in the host plant, these processes will be done within two years depends upon the plant species [21]. Freeze dried plant cells expressing biopharmaceuticals and antigens are shielded in the stomach from acids and enzymes; cell wall of plants and are further protected by their accumulation in the cellular and subcellular compartments, like plastids and seed storage organelles in this way proteins remain protected from, chemical and enzymatic degradation [22] and harsh conditions in the gastrointestinal tract and reach the mucosal surface [23]. When the plant cell wall is digested by microbes present in the gut these antigens and biopharmaceuticals released to immune and blood circulatory system [17,24] these freeze-dried vaccines are subunit vaccines and their stability is desired property at room temperature, for they are consumed orally [25]. Edible vaccines can be used for the treatment of the number of gastrointestinal diseases in infants and children [26]. Lyophilized cells facilitate long-term storage $[18,27]$. The edible parts of fruiting plants containing vaccine are also very fascinating, as fruit or salad can be consumed raw without the loss of vaccine properties [12] in future, it will be easier to get vaccinated through genetically modified food (Figure 1). These vaccines will be preferable for developing countries where conventional medical care is not easily available to the common public, as it removes the need of a medical man and sterile injections [28]. these vaccines are created by familiarizing the desired gene into the DNA of selected fruiting plant, as a plant grows desired protein is produced [29]. The number of researchers is working on this concept for more than twenty years, vast research is performed on hepatitis $B$ vaccine also the variety of plant species have been used to express antigen (like banana as can be consumed raw, is a leading candidate for edible vaccines, at a same time it is all time favorite of children. Potato is drought resistant and largely cultivated likewise, strawberry, apple, maize, tomato [30] are studied in number of beneficial researches for edible vaccine development most prominent studies include the development of plant-based vaccines for HCV, HBV [31] Influenza vaccines [32] respiratory syndrome virus and HIV vaccines [33]. Parenteral delivery of plant-based vaccines is well known and verified requires purification before delivery of antigens [34].

\section{Automated Production in Plant Factories}

Plant-based production of pharmaceuticals is inexpensive, as the presence of chaperones and protein disulfide isomerases allows folding and assembly of complex proteins [35]. A fully automated plant factory for the growth of tobacco plant is an example, where tobacco plants are cultivated in automated factory and agrobacteria having lofty copy of vector are introduced into the plant leaves, by automated vacuum infiltration technique, plants are harvested ground and the proteins are extracted and purified [36]. For plants based recombinant protein production current good manufacturing practices (CGMP) factory which is fully automated works for the production of biopharmaceuticals Table 1. Closed Plant Production System CPES, is a plant factory with artificial lighting is preferable to produce pharmaceuticals it allows stable plant production in controlled environmental conditions like light, temperature, humidity, and gas ensure efficient use of carbon dioxide gas and water.

\section{Advantages}

It is less dominant infrastructure, low operating costs, no need of bioreactors, aseptic liquid handling technologies production multiple products simultaneously, reduce production cycles from month to days, the plants are grown hydroponically in a rigid tray, the tray can be manipulated by automated machinery. Plant biopharming has four main production steps:

- Seeding

- Growth

- Infiltration

- Harvesting

\section{Robotic Transport in Plant Factories}

Robots carry empty trays to seeding module and transported to the growth module in growth module seeds are automatically watered for several and transferred to infiltration module where viral vectors are inserted to the plants and after this plants are allowed to grow further to facilitate the production of proteins, lastly trays are moved to the harvesting module and chopped into small pieces after extraction and purification, this enables cost-effective safe and fast vaccine production. Fraunhofer center for biotechnology research select tobacco plant as expression system because they multiply and maintain virus vectors well, the process begins and a robot picks up a tray containing plants, submerging the head of plants first in to the liquid by turning plants upside down, liquid contains water with vectors containing gene of interest the process is called infiltration [37] then plants are sent back to the growth module, the protein needed is produced within 1 week, after which the plants are harvested, leaves are cut down into small pieces and protein of interest is extracted and purified (Figure 2) $[38,39]$.

\section{Selection of host system}

In E. coli in prokaryote [40] and Chinese hamster ovary cells [41] Pichia pastoris [42], Saccharomyces cerevisiae in eukaryotes expression
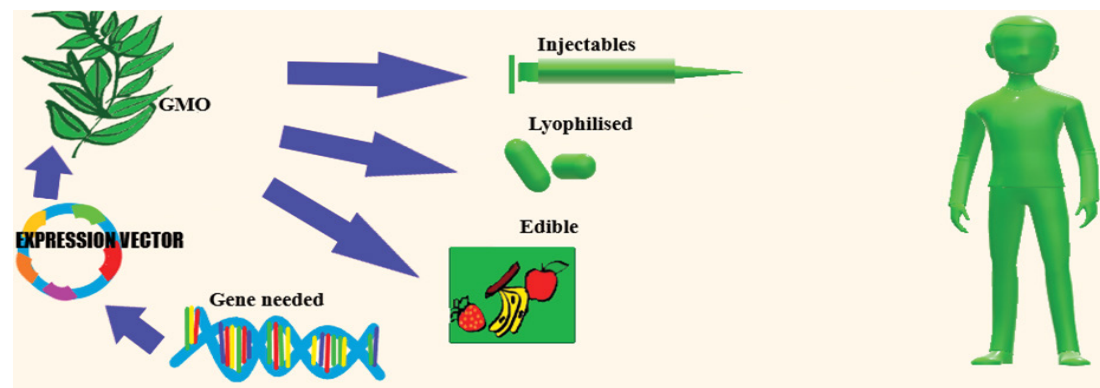

Figure 1: Genetically modified plant containing the gene of interest will produce protein needed, proteins are extracted and purified can be used as injected through parental route, plant leaves are freeze-dried and taken as tablets through oral route as oral vaccines, the edible parts like fruits can be consumed raw to develop immunity [28]. 
Citation: Iqbal RK, Khalid J, Tayyab A, Sattar M, Ansar F, et al. (2018) Vaccination and Biopharming Technology. J Biomol Res Ther 7: 168. doi:10.4172/2167-7956.1000168

Page 3 of 8

\begin{tabular}{|c|c|c|c|c|}
\hline Company & Products & Focus & Pipeline & Status \\
\hline \multirow{2}{*}{ Siphon } & \multirow{2}{*}{ Monoclonal antibodies } & \multirow{2}{*}{$\begin{array}{c}\text { Oncology \& autoimmune } \\
\text { diseases }\end{array}$} & Anti-HER2ADC & Phase- 3 \\
\hline & & & Trastuzumab & Market authorization \\
\hline \multirow{2}{*}{ Mapp Biopharmaceuticals } & \multirow{2}{*}{$\begin{array}{l}\text { Plant-based } \\
\text { Therapeutics }\end{array}$} & \multirow{2}{*}{$\begin{array}{l}\text { Ebola therapy } \\
\text { HIV }\end{array}$} & ZMapp & Phase-3 \\
\hline & & & MB66 & Phase-1 completed \\
\hline \multirow{2}{*}{ Ventria Bioscience } & \multirow{2}{*}{$\begin{array}{l}\text { Plant based recombinant } \\
\text { proteins \& vaccines }\end{array}$} & \multirow{2}{*}{ Zoonotic diseases } & VEN150 & Phase-2completed \\
\hline & & & VEN120 & Phase-1completed \\
\hline \multirow{3}{*}{ Greenovation } & \multirow{3}{*}{ Moss based Therapeutics } & \multirow{3}{*}{ Orphan diseases } & Moss-AGAL & Phase-1 \\
\hline & & & Moss-FH & Preclinical trails \\
\hline & & & Moss-GAA & Preclinical trails \\
\hline \multirow{3}{*}{ Protalix } & \multirow{3}{*}{ Plant-based enzymes } & \multirow{3}{*}{$\begin{array}{l}\text { Cystic fibrosis, } \\
\text { Fabry disease, immune } \\
\text { \&inflammatory diseases }\end{array}$} & PRX-102 & Phase-3 \\
\hline & & & PRX-110 & Phase-2 \\
\hline & & & OPRX-106 & Phase-2 \\
\hline Medicago & $\begin{array}{c}\text { Plant-based vaccines \& } \\
\text { enzymes }\end{array}$ & Influenza \&Ebola & $\begin{array}{l}\text { VLP Quadrivalent influenza } \\
\text { vaccine }\end{array}$ & Phase-3 \\
\hline Icon Genetics & $\begin{array}{c}\text { Plant-based vaccines \& } \\
\text { enzymes }\end{array}$ & Viral \& bacterial diseases & Norovirus vaccine & Under development \\
\hline Plant Biotechnology & $\begin{array}{c}\text { Plant-based antibodies \& } \\
\text { therapeutics }\end{array}$ & MERS coronavirus \& anthrax & DPP4-Fc & Phase-2 completed \\
\hline
\end{tabular}

Table 1: Showing different biotechnology companies their products, orientation, and pipeline status.

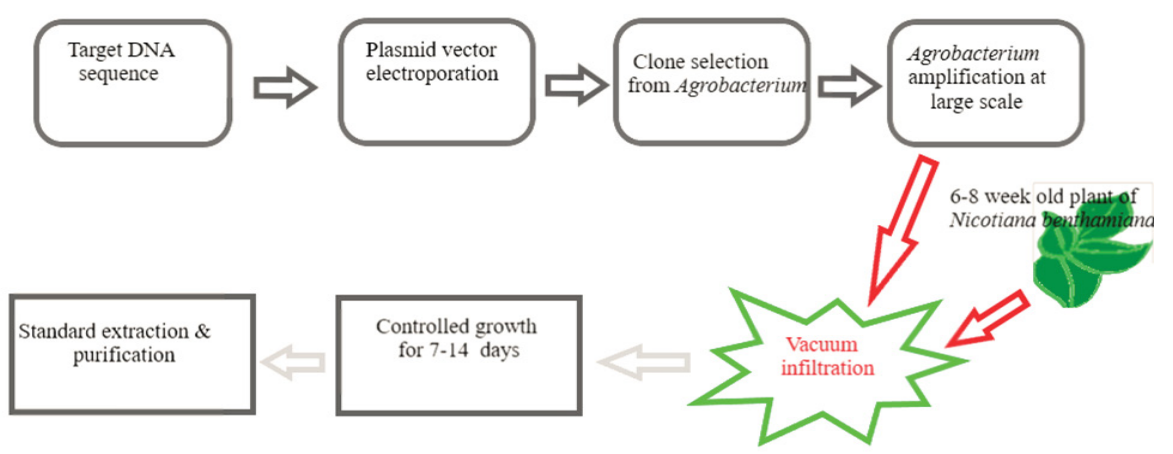

Figure 2: Process of biopharming followed by plant factories [79].

host system has been used for production of biopharmaceuticals, yeast is also a biotechnological host for the production of biopharmaceuticals [43-45] large-scale production of recombinant proteins depends upon microorganisms used to be the best suitable host, proteins expressed in mammalian cells [46] have similar properties as the natural origin, but still it is the less suitable for expression of the therapeutic proteins because of the inability of large-scale production and highly expensive culture cost [47]. Microalgae are being used as a production system for the production of vaccines and biopharmaceuticals $[48,49]$ other new approaches are raised by advancing and rewriting the DNA of host [50] CRISPR has 9 technology can be used for creation off GMOs without the introduction of foreign gene, no doubt gene editing is a powerful technology [51-53]. Plant biotechnology is a joint venture of tissue culture and genetic engineering genetically modified organisms are products with altered genetic material to get desired protein utilizing recombinant technology plant part which is Utilize should be well studied and allow effective risk assessment of the transgene of interest. selection of host system is important for efficient protein production.

- Use self-pollinating plants [54]

- Use leafy plants for huge biomass production

- Use of cereals and leguminous plants

- Tissue that can be consumed raw and should not produce toxic molecules [55]

\section{Plants offer following advantages for the recombinant pro- tein production}

- The lower production cost

- High scale production

- The ability to correct folding

- Post-translational modifications of the expressed proteins

- Minor differences in glycosylation pattern [56]

- Safe articulation frameworks as the plant cells are free from potential human pathogens or prions, oncogenic DNA arrangements and endotoxins.

Plant cells are most suitable for the production of biopharmaceuticals offering the most economical production with simplicity, posttranscriptional modifications and they are free of animal pathogens [57]. Tobacco has huge biomass production capacity. Phenolic compounds may release during an extraction course that might be detrimental to the downstream processing by expression of proteins from leafy crops and this could be unstable green leaf host system is easy to engineer, it can lead to problems if the protein interferes, with plant development and also purification is difficult due to the presence of pigments, alkaloids, and polyphenols [58-60] high protease activity 
and low protein content is another disadvantage of leaf system [61,62]. Tobacco plant have great ability to produce a large amount of green leaf per acre and the Agrobacterium-mediated transformation is successful in tobacco but high amount of nicotine is undesirable, leafy plants have advantage of producing biomass, recent study tobacco is used as an expression system production of immunogens against Herpes Simplex Type 2 [63] but have limited shelf life and unstable protein expression on the other hand proteins stay stable in seeds at room temperature tobacco is being used Seed is main storage organ and helps in downstream processing, avoiding the recombinant protein by phenolic compounds and prevent degradation. Seed is beneficial over the systems as they accrue vast amounts of protein in a comparatively small volume and it provides an environment that may endorse protein accumulation as well as it inhibits degradation that may consequently provide long-term storage [64]. Example of this is antibodies that may present at prominent levels in seeds and stable with no loss of activity [65]. Seeds lack compounds such as phenolic and alkaloids that may present in leaves and obstruct with downstream processing by means of fouling membranes as well as chromatography media. The particular organelles in the seeds present additional advantages such as improved stability and ability for accumulation, bio encapsulation, and enhanced processing approaches for economic purification [66]. Seeds are preferred as they are easily transportable and have enough storage planet biotechnology is one of the leading pharmaceutical companies uses transient and stably transformed tobacco plants for the production of pharmaceuticals and get high levels of expression between 0.5 to 3 grams $/ \mathrm{Kg}$ [67] another company named as Wuhan health gen biotechnology better known as Cryogen uses rice as a host endosperm cell are taken and used to express recombinant proteins [68] likewise seemed is another biotechnology company, uses soybeans as host system for the production of seed-based pharmaceuticals, transgenic soybeans contain $40 \%$ by weight of desired protein [69]. Hairy roots of plants can be used as good mean of producing biopharmaceuticals, is also safe and inexpensive and have been used for production of many recombinant proteins, the proteins expressed in hairy roots are released in to the medium, product purification and homogeneity are the clear benefits of root system, for example hairy roots of tomato were used for the expression of rabies glycoproteins ricin toxin B chain antigen [70]. Every system has its advantages and disadvantages a perfect expression system with all economic features but efficient transformation and regeneration could be helpful to get a better expression system.

\section{Plant transformation types}

There are two main types of transformations, the stable transformation which includes nuclear and chloroplast transformations and second, is transient transformation which includes plant virusbased system.

Nuclear transformation: This transformation involves the integration of foreign gene in the genome of a plant. This may be done either by Agrobacterium-mediated transformation of dicotyledonous or monocot plants by gene-gun method, as leaves of dicots, seeds of dicots and monocots can be utilized for nuclear transformation $[71,72]$ such transformations resulted in genetic expression of recombinant protein gives most stable expression $[73,74]$. Nuclear transformation allows to target proteins to various subcellular regions like endoplasmic reticulum, plastids, vacuole, apoplast, which facilitate correct posttranslational modification (Figure 3).

Chloroplast transformation: This method used to transform chloroplasts by using a gene gun to integrate the transgene into the chloroplast genome [75]. Chloroplast transformation does not give post-translational modifications such as glycosylation [76] for production of heterologous proteins, which does not need the posttranslational modification, high copy number, no gene silencing, multiple genes can be expressed like in operon [73] and integration of gene of interest by homologous recombination $[77,78]$.

Transient expression: Transient expression system utilizes the beneficial characteristics of plant pathogens to infect plants [79] to avoid the escape of pharmaceutical-producing plants to the wild environment we use transient expression strategy, in transient expression, the foreign genetic material does not integrate into the genome of the plant, this could be done via agro-infiltration, viral vectors or by gene gun. Several of binary vectors called $\mathrm{pEAQ}$ vectors for transient expression developed that gives elevated level of transgene expression in very short time [80] secondly, inducible gene promoters are used gene remains inactive and will only activate when sprayed by chemical inducer after harvesting it proves effective as far crop is not damaged by wind or herbivores. However, the protein yield is lower.

Plant viral system: Expression of recombinant protein done by a viral vector is a method for examining protein and its desired character in a plant. Virus infected plants are used to get antigens and antibodies with rapid onset of expression and more than one vector can be used in the same plant. Dicots leaves are most commonly used like of tobacco. The plant produces the high quantity of desired protein within 1-4 weeks of inoculation [81]. Virus-based system consists of two main systems, epitope presenting system, with fused antigens to coat

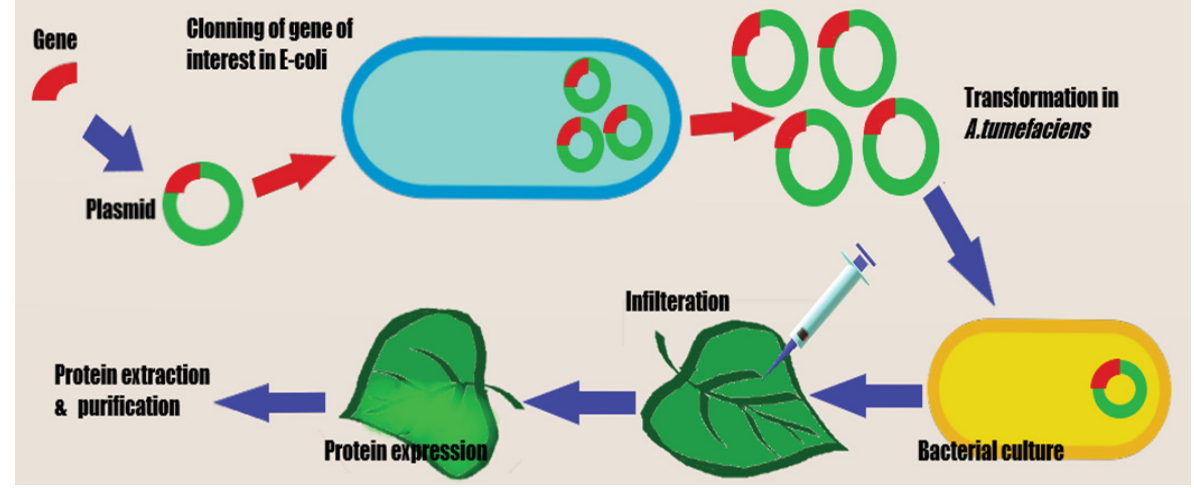

Figure 3: The gene of interest is introduced into the plasmid and cloned in E. coli after cloning is plasmids are transformed in A. tumefaciens the bacterial cell in cultures and then agroinfiltration is done and expressed proteins are extracted and purified [83]. 
Citation: Iqbal RK, Khalid J, Tayyab A, Sattar M, Ansar F, et al. (2018) Vaccination and Biopharming Technology. J Biomol Res Ther 7: 168. doi:10.4172/2167-7956.1000168

Page 5 of 8

proteins and second, is polypeptide expression system, with unfused recombinant proteins which are accumulated by plant but require additional concerns in term of containment [82]

\section{Gene Gun Mediated Transformation in Biopharming}

It is known as Particle Bombardment Biolistic Microprojectile siege Particle increasing speed.

\section{Particle inflow gene gun}

Utilizing a quality weapon specifically shoots a bit of DNA into the beneficiary plant tissue, tungsten or gold dots are covered in the quality of intrigue and discharged through a ceasing screen, quickened by Helium, into the plant tissue, the particles go through the plant cells, leaving the DNA inside, DNA-covered micro carriers are stacked on micro carrier, miniaturized scale transporters are shot towards target tissues amid helium gas decompression, a halting screen set permitting the covered micro projectiles to go through and achieve the objective cells [83-85]

\section{Helios gene gun system}

The helium beat clears the DNA-or RNA-covered gold micro carriers from within mass of the example cartridge, the smaller scale bearers quicken for most extreme entrance as they travel through the barrel, while the helium beat diffuses outward, the spacer keeps up the ideal target separate for in vivo applications and vents the helium gas from the objective to limit cell surface effect (Figure 4) [86,87].

\section{dvantage}

- This method can be used to transform all plant species.

- No binary vector is required.

- Transformation protocol is relatively simple.

\section{Disadvantages}

- Difficulty in obtaining single copy transgenic events.

- Excessive cost of the equipment and micro-carriers.

- Intracellular target is irregular (cytoplasm, core, vacuole, plastid, and so forth).

- Transfer DNA is not protected.

\section{Agrobacterium-mediated transformation}

Agrobacterium tumefaciens is a bacterium that infects plants and causes crown gall disease, because of its ability to transfer the segment of DNA it is used for the production of transgenic plants, researchers have used it by inserting the DNA of interest between the T-DNA of Agrobacterium, after this crown gall disease will not occur as the plasmid is constructed to disarm tumor-inducing characteristics (Figure 5) [88]. Agrobacterium tumefacient-mediated transformation involves the transfer of any DNA located between $25 \mathrm{bp}$ direct repeats present at left and right borders that delimit the single strand T-DNA, is transferred in to the nucleus of plant cell, and integrates into the plant chromosome by illegitimate recombination $[89,90]$ however all of T DNA copies do not integrate but transcribed resulting in transient expression of foreign gene [91] transient expression yields higher protein levels than stable one, and also not affected by position effects [92] transient expression declines sharply after 60-72 hours, as a result, a result of post-transcriptional gene silencing [93]. Agrobacterium strain GV3103 is used for transient expression [94].

\section{Recombinant DNA stability in plant}

Inserting recombinant DNA inside the plant genome may undergo inactivation and prevents its expression inside the plant cell. This DNA inactivation occurs due to the presence of repeated homologous sequences, co-suppression and recombinant DNA methylation [95]. These issues can be overcome by following:

- To incorporated numerous duplicates of DNA

- Overexpression of duplicates of DNA

- Selecting lines with a solitary addition of the transgene

- Not utilizing tedious homologous arrangements

- Selecting stable recombinant lines

- Creating site-particular recombination frameworks

The post-translational alteration is in charge of

- Proper organic action

- Stability and collapsing of the recombinant protein

- Many proteins to amass into the dynamic multimeric frame require complex post-translational adjustment steps.

Glycosylation plays a key role for many physiological activities of a glycoprotein is one of the critical post-translation modifications [96] Phosphorylation is the key factor for the recombinant enzymes which are only activated after phosphorylation. Tyrosine phosphorylation is used by animals, while both the serine-threonine phosphorylation and tyrosine kinase pathway are active in plants.

\section{Optimization of foreign gene sequences for expression in plants}

Yields of any biopharming product are not predictable because

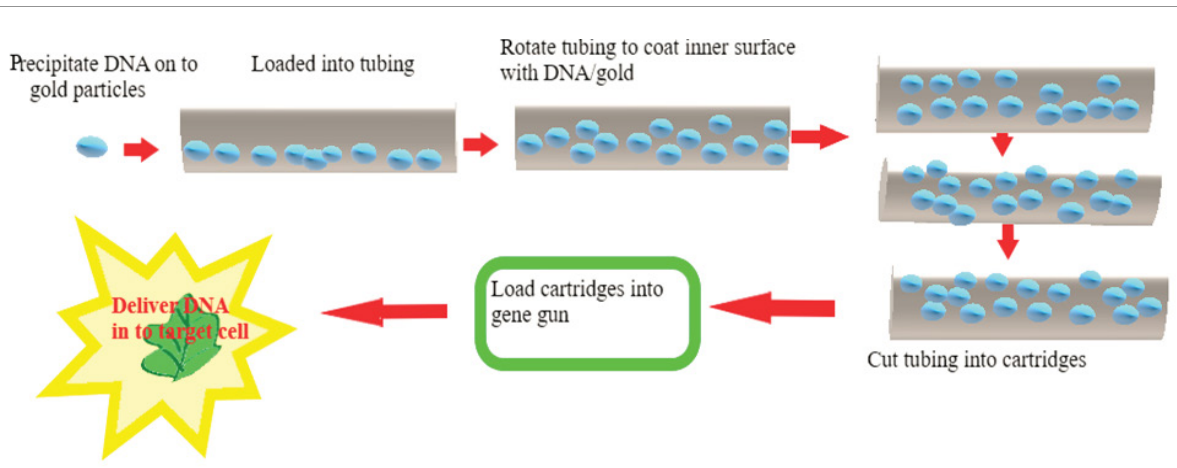

Figure 4: Helios Gene gun. 


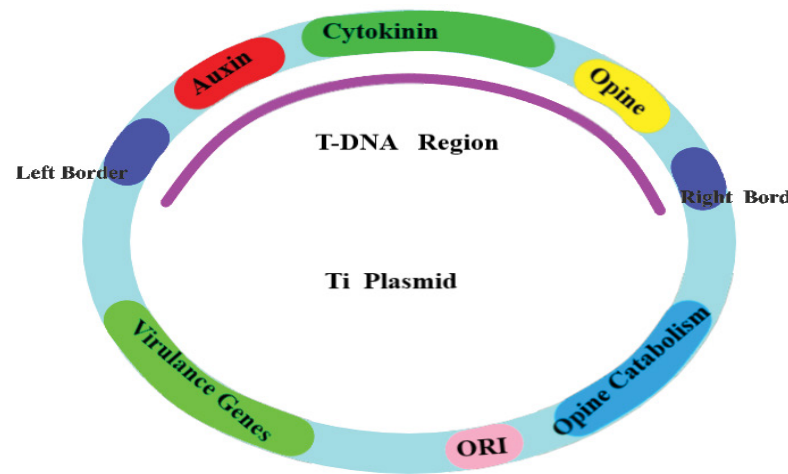

Figure 5: Plasmid construction for Agrobacterium-mediated transformation

it depends on the number of intrinsic properties of proteins, the host and the production strategy. Plants have different codons, yet foreign DNA may optimize for expression in plants to enhance translation and enhance protein yields, expression may be enhanced via, the use of tissue-specific promoters [97] improving transcript stability and viral sequences used for translational enhancement [98]. Protein expression may be enhanced via the use of introns in the recombinant DNA molecule, the suitable promoter selection is a key factor for protein expression by enhancing transcription of foreign gene by that promoter, the foreign gene expression can be targeted to specific tissues of lower metabolic activity like endosperm by using tissuespecific promoter, promoter with wound inducible defense gene are best reported for overexpression of recombinant proteins in plants. Co-expression of host chaperons along with transgene expression is another technique to improve expression, host chaperons gathering could be invoked by heat, membrane fluidizers, and osmolytes, plasmid-derived overexpression may not need [99].

\section{Downstream processing}

Downstream processing usually refers to the recovery and purification of the recombinant protein from plants leaves. The production cost depends on a protein expressed, biomass produced and production scale, greater the biomass greater the processing cost [100]. Processing of leaves necessitate interest, leaves should be processed instantly after harvesting or must be stored to avoid degradation of proteins by proteases. Affinity tags must be used to facilitate protein recovery. These tags then removed after purification to restore the structure of the purified protein from its inhabitant situation. Problems meet at the time of protein extraction mainly includes proteolytic degradation and structural modification, because of the reaction with phenolic compounds [101]. Purification with quantity and quality are challenging for seed system, Purification strategies rely on oleosin fusions in oil bodies or maybe polymer fusions or other sections can develop any suitable process for the isolation of proteins [102]. Approximately more than $80 \%$ of the entire production, cost of recombinant protein is linked with the downstream processing. A plant-based system is beneficial as many of the recombinant proteins can be used as part or unprocessed material reducing the downstream cost. As it's important to increase the production and recovery of the target proteins, endoplasmic reticulum may be essential for the processing, disulfide bond formation, assembly and glycosylation of proteins. Rhizosecretion of recombinant protein in the hydroponic medium in roots is an approach that may help in simplifying the downstream processing and may increase the protein yield.

\section{Conclusion}

Biopharming is recent technology serving in production of various pharmaceutical products which are already being produced in many pharmaceutical companies by bioreactors using algae, bacteria and mammalian cell culture, where production is followed by expensive downstream processing, but in case of plants production is quite suitable and affordable, however challenges remained partially meted in the selection of suitable host system, transformation technology for the production of desired proteins, recombinant gene stability and optimized expression, all of these play their equal role for the attainability of final product, until now biopharmaceuticals are being produced so well and being consumed also but still promising techniques are required to get most accurate, stable and cost-effective expression.

\section{References}

1. https://www.historyofvaccines.org/content/articles/different-types-vaccines

2. Kushnir N, Streatfield SJ, Yusibov V (2012) Virus-like particles as a highly efficient vaccine platform: diversity of targets and production systems and advances in clinical development. Vaccine 31: 58-83

3. van Zyl AR, Hitzeroth II (2016) Purification of Virus-Like Particles (VLPs) from Plants. Methods Mol Biol: 569-579.

4. Rosario K, Fierer N, Miller S, Luongo J, Breitbart M, et al. (2018). A diversity of DNA and RNA viruses in indoor air as assessed via metagenomic sequencing. Environ Sci Technol 52: 1014-1027.

5. Berardi A, Lomonossoff GP, Evans DJ, Barker SA (2017) Plant-expressed Hepatitis $B$ core antigen virus-like particles: Characterization and investigation of their stability in simulated and pig gastro-intestinal fluids. Int J Pharm 522 147-156.

6. Hyun SI (2017) Topological Analysis and Functional Characterization of Vaccinia Virus Morphogenesis Proteins

7. Bartholomaeus A (2018) Regulating Safety of Novel Food and Genetically Modified Crops. Adv Bot Res 86: 89-110.

8. Thakur A (2017) Evaluation of biological control strategies against a range of plant pathogens.

9. De Santis B, Stockhofe N, Wal JM, Weesendorp E, Lallès JP, et al. (2018) Case studies on genetically modified organisms (GMOs): Potential risk scenarios and associated health indicators. Food Chem Tox 117: 36-65.

10. Klocko AL, Lu H, Magnuson A, Brunner A, Ma C, et al. (2018) Phenotypic expression and stability in a large-scale field study of genetically engineered poplars containing sexual containment transgenes. Front Bioeng Biotechno 6: 100.

11. Gaur RK, Verma RK, Khurana SM (2018) Genetic Engineering of Horticultura Crops. Present Future Genetic Engineering of Horticultural Crops 7: 23-46.

12. http://medicarepharmabusiness.com/edible-vaccines/

13. Elkholy SF, Ismail RM, Bahieldin A, Sadik AS, Madkour MA, et al. (2009) Expression of hepatitis $B$ surface antigen ( $\mathrm{HBsAg})$ gene in transgenic banana (Musa Spl). Arab J Biotechnol 12: 291-302.

14. Byrne P (2003) Bio-pharming. Crop series. Production No. 0.307

15. Volpe $L$ (2016) Optimization of a Biotechnological Process for Production and Purification of Two Recombinant Proteins: Col G and Col H. CET 49: 61-66.

16. Sohrab SS, Suhail M, Kamal MA, Husen A, Azhar EI (2017) Edible vaccine: current status and future perspectives. Curr Drug Metab 18: 831-841.

17. Kwon KC, Verma D, Singh ND, Herzog R, Daniell H, et al. (2013) Oral delivery of human biopharmaceuticals, autoantigens and vaccine antigens encapsulated in plant cells. Adv Drug Deliv Rev 65: 782-799.

18. Kwon KC, Sherman A, Chang WJ, Kamesh A, Biswas M, et al.(2017) Expression and assembly of largest foreign protein in chloroplasts: oral delivery of human FVIII made in lettuce chloroplasts robustly suppresses inhibitor formation in hemophilia A mice. Plant Biotech J 16: 1148-1160.

19. van Rijssen WJ, Morris EJ (2018) Safety and Risk Assessment of Food From 
Citation: Iqbal RK, Khalid J, Tayyab A, Sattar M, Ansar F, et al. (2018) Vaccination and Biopharming Technology. J Biomol Res Ther 7: 168. doi:10.4172/2167-7956.1000168

Page 7 of 8

Genetically Engineered Crops and Animals: The Challenges Genetically Engineered Foods. Genet Eng Food 21: 335-368.

20. Giddings $\mathrm{G}$ (2001) Transgenic plants as protein factories. Current Opinion in Biotechnology. Curr Opin Biotechnol 12: 450-454.

21. Hood EE, Woodard SL, Horn ME (2002) Monoclonal antibody manufacturing in transgenic plants-myths and realities. Curr Opin Biotechnol 13: 630-635.

22. Tanuja P, Kumar AL (2017) Transgenic Fruit Crops-A Review. Int J Curr Microbiol App Sci 6: 2030-2037.

23. Sack M, Hofbauer A, Fischer R, Stoger E (2015) The increasing value of plantmade proteins. Curr Opin Biotech 32: 163-170.

24. Dmour I, Taha MO (2018) Natural and semisynthetic polymers in pharmaceutical nanotechnology. Org Mat Sma Nanocarr Drug Deliv 22: 35-100.

25. Arntzen C, Plotkin S, Dodet B (2005) Plant-derived vaccines and antibodies: potential and limitations. Vaccine 23: 1753-1756.

26. Rogalska T, Day JC, AbouHaidar M, Hefferon K (2011) Current status of plants as vaccine production platforms. J Clin Cell Immunol S4: 003.

27. Chan HT, Daniell H (2015) Plant $\square$ made oral vaccines against human infectious diseases-are we there yet? Plant Biotechnol J 13: 1056-1070

28. Yao J, Weng Y, Dickey A, Wang KY (2015) Plants as factories for human pharmaceuticals: applications and challenges. Int J Mol Sci 16: 28549-28565.

29. Hirlekar RS, Bhairy SR (2017) Edible vaccines: An advancement in oral immunization. Asi J Pharm Clin Res 10: 71

30. Sohrab SS, Suhail M, Kamal MA, Husen A, Azhar El et al. (2017) Edible vaccine: current status and future perspectives. Curr Drug Metab 18: 831-841.

31. Venkataraman S, Huang T, Zamani-Babgohari M, Haidar MGA, Hefferon KL. Hepatitis: A Global Health Concern.

32. Mardanova ES, Ravin NV (2018) Plant-produced Recombinant Influenza A Vaccines Based on the M2e Peptide. Curr Pharm Des 24: 1317-1324.

33. Hoelscher M, Tiller N, Teh AY, Wu H, Ma JK, et al. (2018) High-level expression of the HIV entry inhibitor griffithsin from the plastid genome and retention of biological activity in dried tobacco leaves. Plant Mol Biol 97: 357-370.

34. Pniewski T (2013) The twenty-year story of a plant-based vaccine agains hepatitis B: stagnation or promising prospects? Int J Mol Sci 14: 1978-1998.

35. Tschofen M, Knopp D, Hood E, Stöger E (2016) Plant molecular farming: much more than medicines. Annu Rev Anal Chem 9: 271-294.

36. Wirz H, Sauer-Budge AF, Briggs J, Sharpe A, Shu S, et al. (2012) Automated production of plant-based vaccines and pharmaceuticals. J Lab Autom 17: 449-457.

37. Pang E L (2018) Molecular pharming of consensus dengue viral envelope glycoprotein domain III in planta and its immunogenicity profiles in BALB/C mice. The University of Nottingham.

38. http://www.robaid.com/tech/automated-plant-factory-for-the-production-ofvaccines.html

39. https://www.ime.fraunhofer.de/en/About_Us.html

40. Studier FW (2018) T7 Expression Systems for Inducible Production of Proteins from Cloned Genes in E. coli. Curr Protoc Mol Bio 124: e63.

41. Foley SL (2018) The plethora of Potential Platforms: a review of current and future trends in expression system choice in the biopharmaceutical industry. Institute of Technology. Sligo.

42. Vogl T, Sturmberger L, Fauland PC, Hyden P, Fischer JE, et al. (2018) Methano independent induction in Pichia pastoris by simple derepressed overexpression of single transcription factors. Biotechnol Bioeng 115: 1037-1050.

43. Vogl T, Gebbie L, Palfreyman RW, Speight R (2018) Effect of plasmid design and type of integration event on recombinant protein expression in Pichia pastoris. Appl Environ Microbiol 84: e02712-17.

44. Katz L, Chen YY, Gonzalez R, Peterson TC, Zhao H, et al.(2018) Synthetic biology advances and applications in the biotechnology industry: a perspective. $J$ Indus Microbiol Biotechnol 45: 449-461.

45. Kotopka BJ, Li Y, Smolke CD (2018) Synthetic biology strategies toward heterologous phytochemical production. Nat Prod Rep 35: 902-920.

46. Vazquez-Lombardi R, Nevoltris D, Luthra A, Schofield P, Zimmermann C, et al. (2018) Transient expression of human antibodies in mammalian cells. Nat Protoc 13: 99-117.

47. Majumdar Dd. Plants as Biofactories for The Production of Biopharmaceuticals: A Brief Review. IJBTR 3: 17-32.

48. Little A, Schwerdt JG, Shirley NJ, Khor SF, Neumann K, et al. (2018). Revised phylogeny of the Cellulose Synthase gene superfamily: insights into cell wall evolution. Plant Physio 177: 1124-1141.

49. Spicer A, Molnar A (2018) Gene Editing of Microalgae: Scientific Progress and Regulatory Challenges in Europe. Biology 7: 21.

50. Collins JH, Young EM (2018) Genetic engineering of host organisms for pharmaceutical synthesis. Curr Opin Biotech 53: 191-200.

51. Nogueira M, Enfissi EM, Almeida J, Fraser PD (2018) Creating plant molecular factories for industrial and nutritional isoprenoid production. Curr Opin Biotech 49: $80-87$

52. Zou X, Wang L, Li Z, Luo J, Wang Y, et al. (2018) Genome engineering and modification toward synthetic biology for the production of antibiotics. Med Res Rev 38: 229-260.

53. Piatek AA, Lenaghan SC, Stewart Jr CN (2018) Advanced editing of the nuclear and plastid genomes in plants. Plant Sci 273: 42-49.

54. Murphy DJ (2007) Improving containment strategies in biopharming. Plant Biotech J 5: 555-569.

55. Tiwari S, Verma PC, Singh PK, Tuli R (2009) Plants as bioreactors for the production of vaccine antigens. Biotechnol Adv 27: 449-467.

56. Ma JK, Drake PM, Christou P (2003) Genetic modification: the production of recombinant pharmaceutical proteins in plants. Nat Rev Genet 4: 794-805

57. Sharma R, Sathish KR (2017) Rapid Production of therapeutic Proteins using Plant System. DLSJ 2: 95.

58. Rybicki EP (2009) Plant-produced vaccines: promise and reality. Drug Discov Today 14: 16-24.

59. Jelaska S, Mihaljevic S, Bauer N (2005) Production of biopharmaceuticals, antibodies and edible vaccines in transgenic plants. Curr Stud Biotechnol 4 121-127.

60. Mama AO, Munyendo WL (2018) Contemporary Advances and Precincts of Biopharming as Drugs' Production Systems 8: 1-7.

61. Chan XY (2017) Molecular expression of recombinant Apoptin in planta and preliminary evaluation of biological characteristics of plant-made Apoptin on cancerous cells. The University of Nottingham.

62. https://air.unimi.it/handle/2434/489689\#.W9Ky6JMzbIU

63. El-Attar A, Aboul-Ata AA, Persson J, Mazyad H, Harandi, AM, et al. (2018) Recombinant TMV Vector for Production of Highly Immunogenic Plant-Based Vaccine Antigens Against Herpes Simplex Virus Type 2.

64. Drake PM, Barbi T, Sexton A, McGowan E, Stadlmann J, et al. (2009) Development of rhizosecretion as a production system for recombinant proteins from hydroponic cultivated tobacco. FASEB J 23: 3581-3589.

65. Stöger E, Vaquero C, Torres E, Sack M, Nicholson L, et al. (2000) Cereal crops as viable production and storage systems for pharmaceutical scFv antibodies. Plant Mol Biol 42: 583-590.

66. Sabalza M, Vamvaka E, Christou P, Capell T (2013) Seeds as a production system for molecular pharming applications: status and prospects. Current Pharmaceutical Design 19: 5543-5552.

67. http://www.planetbiotechnology.com/index.html

68. https://www.antibodies-online.com/supplier/Oryzogen/

69. https://www.soymeds.net/bio-tech-products.htm

70. Singh A, Srivastava S, Chouksey A, Panwar BS, Verma PC, et al. (2015) Expression of Rabies Glycoprotein and Ricin Toxin B Chain (RGP-RTB) fusion protein in tomato hairy roots: a step towards oral vaccination for rabies. Molecular Biotechnology 57: 359-370.

71. Streatfield SJ (2007) Approaches to achieve high $\square$ level heterologous protein production in plants. Plant Biotechnol J 5: 2-15.

72. Ahmad K (2014) Molecular farming: strategies, expression systems, and biosafety considerations. Czech J Genet Plant Breed 50: 1-10. 
Citation: Iqbal RK, Khalid J, Tayyab A, Sattar M, Ansar F, et al. (2018) Vaccination and Biopharming Technology. J Biomol Res Ther 7: 168. doi:10.4172/2167-7956.1000168

73. Desai PN, Shrivastava N, Padh H (2010) Production of heterologous proteins in plants: strategies for optimal expression. Biotechnology Advances 28: 427-435.

74. Husaini AM, Abdin MZ, Parray GA, Sanghera GS, Murtaza I, et al. (2010) Vehicles and ways for efficient nuclear transformation in plants. GM Crops 1: 276-287

75. Daniell H (2006) Production of biopharmaceuticals and vaccines in plants via the chloroplast genome. Biotechnol J 1: 1071-1079.

76. Boehm R (2007) Bioproduction of therapeutic proteins in the 21st century and the role of plants and plant cells as production platforms. Ann NY Acad Sci 1102: $121-134$

77. Adem M, Beyene D, Feyissa T (2017) Recent achievements obtained by chloroplast transformation. Plant Methods 13: 30

78. Legen J, Ruf S, Kroop X, Wang G, Barkan A, et al. (2018) Stabilization and translation of synthetic operon $\square$ derived mRNA s in chloroplasts by sequences representing PPR protein $\square$ binding sites. The Plant J 94: 8-21.

79. Stoger E, Fischer R, Moloney M, Ma JK (2014) Plant molecular pharming for the treatment of chronic and infectious diseases. Annual Review of Plant Biology 65: 743-768.

80. Sainsbury F, Thuenemann EC, Lomonossoff GP (2009) pEAQ: versatile expression vectors for easy and quick transient expression of heterologous proteins in plants. Plant Biotechnol J 7: 682-693.

81. Bagheri S, Fakheri BA (2014) Plants as factories for the Production of Pharmaceutical recombinant proteins. Bull Env Pharmacol Life Sci 3: 149-155.

82. Twyman RM, Stoger E, Schillberg S, Christou P, Fischer R, et al. (2003) Molecular farming in plants: host systems and expression technology. Trends Biotechnol 21: 570-578.

83. Marsian J, Lomonossoff GP (2016) Molecular pharming- VLPs made in plants. Curr Opin Biotechnol 37: 201-206.

84. https://scholarship.claremont.edu/cmc_theses/1824/

85. Lyle C (2018) Immunostimulatory Effects of Antigen-Conjugated InP/ZnS Quantum Dot Nanoparticles in an Avian Model.

86. Zobayer M, Mukhlish B (2018) Development of Flexible Ceramic Nanofiber Membranes for Energy and Environmental Applications.

87. Cunningham FJ, Goh NS, Demirer GS, Matos JL, Landry MP, et al. (2018) Nanoparticle-Mediated Delivery towards Advancing Plant Genetic Engineering. Trends Biotechnol 36: 882-897.

88. Shama L, Peterson RK (2004) The benefits and risks of producing pharmaceutical proteins in plants. Risk Management Matters 2: 28-33.
89. Somers DA, Makarevitch I (2004) Transgene integration in plants: poking or patching holes in promiscuous genomes? Curr Opin Biotechnol 15: 126-131.

90. Mini P, Demurtas OC, Valentini S, Pallara P, Aprea G, et al. (2018) Agrobacterium-mediated and electroporation-mediated transformation of Chlamydomonas reinhardtii: a comparative study. BMC Biotechnology 18: 11.

91. Maclean J, Koekemoer M, Olivier A, Stewart D, Hitzeroth I, et al. (2007) Optimization of human papillomavirus type 16 (HPV-16) L1 expression in plants: comparison of the suitability of different HPV-16 L1 gene variants and different cell-compartment localization. J General Virology 88: 1460-1469.

92. Kapila J, De Rycke R, Van Montagu M, Angenon G (1997) An Agrobacteriummediated transient gene expression system for intact leaves. Plant Sci 122 101-108.

93. Voinnet $\mathrm{O}$ (2001) RNA silencing as a plant immune system against viruses. Trends Genet 17: 449-459.

94. Xu H, Moghe GD, Wiegert-Rininger K, Schilmiller AL, Barry CS (2018) Coexpression analysis identifies two oxidoreductases involved in the biosynthesis of the monoterpene acid moiety of natural pyrethrin insecticides in Tanacetum cinerariifolium. Plant Physiol 176: 524-537.

95. Shrestha A, Khan A, Dey N (2018) Cis-Trans Engineering: Advances and Perspectives on Customized Transcriptional Regulation in Plants. Molecular Plant 11: 886-898.

96. O’Flaherty R, Trbojević-Akmačić I, Greville G, Rudd PM, Lauc G (2018) The sweet spot for biologics: recent advances in the characterization of biotherapeutic glycoproteins. Expert Rev Proteomics 15: 13-29.

97. Romanova N, Noll $T$ (2018) Engineered and natural promoters and chromatin $\square$ modifying elements for recombinant protein expression in $\mathrm{CHO}$ cells. Biotechnology J 13: 1700232.

98. Ko K, Koprowski H (2005) Plant biopharming of monoclonal antibodies. Virus Res 111: 93-100.

99. Rennig M, Andersen, MR (2017). Synthetic biology approaches for protein production optimization in bacterial cell factories. Novo Nordisk Foundation Center for Biosustainability.

100. Martínez-Alarcón D, Blanco Labra A, García Gasca T (2018) Expression of Lectins in Heterologous Systems. Int J Mol Sci 19: 616.

101. Jackson MA, Gilding EK, Shafee T, Harris KS, Kaas Q, et al. (2018) Molecular basis for the production of cyclic peptides by plant asparaginyl endopeptidases. Nat Commun 9: 2411

102. Daniell H, Streatfield SJ, Wycoff K (2001) Medical molecular farming production of antibodies, biopharmaceuticals and edible vaccines in plants. Tren Plant Sci 6: 219-226. 